\title{
Analysis and Comparison of Naturalistic Themes in Iranian and Britain Modern Children's Poems
}

\author{
Shayesteh Ebrahimi \\ Department of Persian language and literature, Science and Research Branch, Islamic Azad University, Tehran, Iran \\ E-mail: sh.ebrahimi83@gmail.com \\ Parvin Saljeghe (Corresponding author) \\ Islamic Azad University, Central Tehran Branch, Tehran, Iran \\ E-mail: salajeghe@gmail.com
}

Doi:10.7575/aiac.alls.v.7n.4p.181

URL: http://dx.doi.org/10.7575/aiac.alls.v.7n.4p.181
Received: 09/04/2016

Accepted: 21/06/2016

\begin{abstract}
Today, children's literature given the concept of childhood, has gained a special status in the studies of humanities. Children's poetry is one of the branches of this type of literature. Naturalistic themes have the highest frequency among the themes of children poems in two countries. The population of this research consists of collections that have been published from 1921 to 2011. Children's literature was born in England in the eighteenth century and before that the first didactic books for children had come into existence in England. In addition, due to industrial growth, the emergence of the new middle class and expansion of formal education the UK was pioneering among Europe and the world countries. Therefore, to find the roots of the formation of children's literature should be referred to the UK. Therefore, in this paper Britain children's poem has been selected to be compared with Iranian children's poem so that by revealing the similarities and differences one can deal with the pathology of poems for children in Iran and to detect shortcomings and strengths and present some guidelines that be helpful for children and young poets as well as critics and researchers in this field.
\end{abstract}

Keywords: Naturalistic themes, children literature, Iranian children's poems, Britain children's poems, comparative literature

\section{Introduction}

The second half of the seventeenth century can be considered as a starting point in the history of children's literature in the world, that's because of publishing books such as The Visible World visible in Pictures (1954) by John Amos Comenius where children are studies as independent existence, and A Token for Children by James Janeway (16361674) that was the story of sacred lives and delightful death of several children. One of the reasons to invent such a genre in the texts of the history of literature in the seventeenth century is that in this period some books were published that were written specifically for children. Although these books were merely educational and didactic and moral, but because they were written especially for children, they were considered significant; prior to this time, children's books were anthologies extracted from adult texts. Since the second half of the eighteenth century, by thriving the ideas of thinkers like John Locke and Jean-Jacques Rousseau, childhood gained value and credibility and was recognized as a valuable part of human life. Locke ideas were an invitation for the book producers to fill in the gaps and write a variety of books for children as well as didactic books and books full of religious and moral teachings. John Newbery, who was supporters of Locke theory, is the first specialty publisher of children's books. Newbury was at the same time an author, a publisher and a bookseller. Around 1740, he opened a bookshop in London and began to publish and sell small packet books for the children; therefore, it can be said that modern children's literature was born in England in the mid eighteenth century. In fact, more previously the first moral and didactic books for children had been written in the seventeenth century by Puritan.

Since the mid-eighteenth century to the present, literature for children and teenagers are recognized as a serious and independent phenomenon in the West, which has always been in the path of evolution, innovation and progress to the point that now criticism and theories of children and adolescents literature are considered as a dynamic branch of academic researches. But an independent children's literature in Iran shaped almost one hundred and fifty years after the West; as Iran constitutional revolution hugely transformed Iran's literature and art, it significantly influenced children's literature too. The works that were written specifically for children without having a didactic and educational aspect were published for the first time in Iran in the Constitution period. More specifically, it can be said that the first books for children were published around 1920by Jabbar Baghcheban.

Children's poetry is a branch of children's literature. As mentioned, children's poetry in Iran comes into existence later than in the West. In classical Persian literature, some poems can be found dealing with child and childhood or even addresses children and adolescences, often written for the purpose of educating the children. However, modern 
children's poetry was shaped after Constitution event. Jabbar Baghcheban, Abbas Yamini Sharif, Parvin Dolat Abadi and Mahmoud Kianoosh are some pioneers of children's poetry in Iran.

As mentioned, children's literature was born in England in the eighteenth century and before this time, the first didactic books for children had come into existence in England. In addition, due to industrial growth, the emergence of the new middle class and expansion of formal education, the UK was a progressive country among the rest of countries in Europe and in the world. Therefore, to find the roots of the formation of children's literature one should be referred to the UK.

Our population in this study consists of collections published from 1921 to 2011; however, as dealing with this volume of works is beyond the capacity of the present study and it takes several months and years. Also, in order to achieve an academic and applied methodology, we decided to discuss the most prominent poets of both countries and among the works of these poets we selected those that have received several awards over these years. The awards in Iran include the poetry prize of Institute for the Intellectual Development of Children and Young Adults, the prize of Children's Book Council, the prize of the Book of Season and the Pupak Poetry Prize. In the UK, unlike Iran, the number of awards is limited; there is to prize for children's poetry that are called the signal poetry award and CLPE poetry award.

\section{Analysis of Naturalistic Themes}

In this study, a total of 2528 poems were examined; in 1411 poems by Iranian poets and 1117 poems by English poets. From 1411 of studied poems by Iranian poets, 585 poems, equivalent to $41 \%$ and from 1117 studied poems by English poets 436 poems equivalent to $39 \%$ have naturalistic themes. In both groups, naturalistic themes have the highest number of poetry. In fact, it is obvious that this theme has been the most popular one for children's poets.

According to Jacques charpentreau, still various aspects of nature is the main subject of poems and still when "I ask readers of magazines what they like most about the poems, most of them say the interesting account of nature.”(Charpentreau, 1993, p. 204).

Jean Piaget, psychologists and other critics in the field have paid significant attention to the proportion between desires and psychological characteristics of children with the nature. Perhaps, such a proportion is one of the reasons why poets consciously and unconsciously pay attention to the nature; among them Piaget argues "for children, the boundary between animate and inanimate fades away. They assume everything to be animate and attribute the life and its effects to all objects and phenomena surrounding them (Belali, 2000, p. 12).

However, in the kind of the attitudes of the two groups of poets to the nature and processing the naturalistic themes in their poetries significant differences are observed. In the following we will discuss these differences and similarities.

\subsection{Animals}

Both groups of poets have paid more attention to animals than plants because according to Piaget's findings "in children's thinking, the basis of being animate in the phenomena is their mobility" (ibid ,p. 11). However, the viewing angle of the poets in both groups is very different, Iranian poets have spoken of animals that children deal with them and may also see them in their everyday life such as pets and domestic animals, birds, insects and ...But English poets have included wild animals in their descriptions; like this poetry by Ted Hughes as "spell" in which the Wolf has been described in a different connection with nature and in some ways it is reminiscent of the views of Shamanic:

"Inside the wolf's fang, the mountain of heather.

Inside the mountain of heather, the wolf's fur.

Inside the wolf's fur, the raghed forest.

Inside the raghed forest, the wolf's foot.

Inside the wolf's foot, the stony horizon.

Inside the stony horizon, the wolf's tongue.

Inside the wolf's tongue, the doe's tears.

Inside the doe's tears, the frozen swamp.

Inside the frozen swamp, the wolf's blood.

Inside the wolf's blood, the snow wind.

Inside the snow wind, the wolf's eye.

Inside the wolf's eye, the North star.

Inside the North star, the wolf's fang." (Hughes, 1978, p. 18)

Also, in the kind of attitude to both domestic and wild animals significant differences can be seen; thus, Iranian poets have not paid attention to the nature and existence of the animal but most of them have presented the animals in the form of human characters or have introduced them with the same stereotypical characters in the stories and folklore such as wily fox, guard dog, early rising rooster and mignon cat...

When the subject of the poem is the crow, the poet focuses on its "caw caw"; that is, he describes the crow as a noisy bird with black feather: 
"My noisy magpie/my naughty and mulish bird

Wherever my dad works/it caws it caws"(Yamini Sharifi, 2008, p.7)

Or

The rooster is a bird informs coming of the morning:

"I am the rooster/bringing good news/it's the dawn/my eyes I open/my wings I flap" (ibid, p. 45)

Sometimes, both groups speak instead of the animals to describe them; however, the difference is that in the poems of English poets it seems that the very animals have started speaking and are animate creatures with sense and consciousness. The poets try to think as an animal and write the poem from its viewing angle; however, in the works of Iranian poets when the animal describes himself as if a man talked and introduced himself. Of course, at times in the works of recent Iranian poets we encounter poems that have paid attention to the appearance of animal too; like this poem that has described the worm in the apple:

"Outing had I gone today/into a ripe apple/a worm was there/ a wt pale worm" (Keshavarz, 2004, p. 38).

Similarly, Iranian poets have described the animals often according to the impact they have on human being life; for example, they speak about fly as a dirty insect that transmit the disease, mosquito an insect that bite and hen as an animal that lay eggs for human beings. However, English poets, as mentioned, consider animals as sensible creatures and describe them in the position of an animal with the nature and character of an animal. To illustrate these differences, we allude to a sample of descriptions of the poets in both group of the same animal:

There is a poem by Ted Hughes, the poet of animals and the nature, under the title of "The Hen" that says:

"The hen worships the dust. She finds God everywhere.

Everywhere he finds his jewels.

And she does not care

What the cabbage thinks." (Hughes, 2010, p. 238)

And a poem entitled "The Hen" by Abbas Yamini Sharifi, who can be called the poet of animals and the natures too due to his high frequency poems about the animals:

"cluck cluck cluck cluck/ hey children hey children/this egg I've laid/with my yolk and white egg/again if help me/keep me well/each day a nice egg/a big and snowy egg/hear I lay you (Yamini Sharifi, 2008, p. 4).

Both group of poets denounce the captivity and harassment of animals, but wild animals are not object of Iranian poets they only speak about the birds in the cage and English poets campaign against hunting, captivity of wild animals as well as domestic animals:

"Green Indian parrot / come from the forest / with sweet stories / to our town you come / but now in the cage / you're in a bad-mood I guess / say with yourself / men's heart is of stone” (Kianoosh, 1990 , p. 8).

"I saw a jolly hunter

Whith a jolly gun

Walking in the country

In the jolly sun

In the jolly meadow

Sat a jolly hare

Saw the jolly hunter

Took jolly care

Bang went the jolly gun

Hunter jolly dead

Jolly hare gote clean away

Jolly good , I said." (Causley, 1973, p. 9-10)

Both group of poets invite the children to be friend with pets and domestic animals, however, the distinguishing point is that Iranian poets consider and describe these animals as human beings like this examples:

"Cute and tiny cat / stroll comfortably and happy / wherever you wish / Go and walk freely / like God Darwish / be guest in all homes / familiar with everyone / you're among the people" (Kianoosh, 1991, p. 136).

"Our neighbor has a chick/nice and yellow and peeping/in our home we have a cat/follow it smelling/I know that our cat /won't hurt it/just want to play/I wish our neighbor knew" (Ghasemnia, 1994, p. 14).

but English poets describe them as animals, even pay attention to some wild aspects of these animals and their real lives that may have away from human beings:

"You need your Cat.

When you slump down 
All tired and flat

With too much town..." (Hughes, 1987, unnumbered)

It seems that some English poets in the context of this kind of realistic look at the animals are followers of DH Lawrence. Lawrence is one of the first poets whose poems addressed the nature and wildlife in a form which was realistic and away from the Symbolism.as An example, among the English poets, Ted Hughes can be named. Lockwood In this regard says: "some of Hughes' most memorable poems, for children or adults, reminiscent at times of the close observation and imaginative reach of D. H .Lawrence's collection Birds, Beasts and Flowers (1923), which Hughes also knew well." (Lockwood, 2009, p.302)

\title{
2.2 Preservation and Vegetarian
}

New themes such as encouraging vegetarianism can be seen in English poems, which have no example in Iranian poems:

\author{
"Dis ting is serious \\ Doit for all of us \\ Save our asparagus, \\ God save \\ Our \\ Green" (Zephania, 1996)
}

However, themes such as the fight against plant construction and invitations to take care of the tree and natural resources are abundant in Iranian poetry:

"Gradually come to us from distant / evil people / rapidly made the house / on the soil and water / factory like dragon" (Shabani, 1993 , unnumbered).

"Cypress tree fell on the ground / sky irritated / from the jungle book / a green poem decreased"(Keshavarz, 1998, p. 2).

Moreover, some Iranian poets in recent years in poems about fruits, plants and trees have paid attention to some aspects of lives of these creatures that are unimportant to others and this attitude is often accompanied with compassion for these creatures. In fact, they try to teach the children that they can have a different attitude to the fruits; they draw the attention of the children to the nature and truth of fruits in the nature and ask them not to see the fruits just as a food or a means to provide the body with vitamins and necessary materials, but also as useful and worthy creatures and enjoy eating the fruits, respect them and know that now when the fruits are eaten, they are a part of their existence, for example in a poem titled "alas, no smile", the poet speaks in place of the apple:

"Neither said a word to me/nor admired me/just he weighted me/again and again/what he wanted me/none other than vitamin" (Keshavarz, 2004 , p.10).

English poets have greatly focused on preserving the environment; for example, for example Roger Mc Gough in poems titled " Aquarium", " Aviary" and " Cocks and Hens" has wholly spoken about; " Aquarium" is about the sufferings of a tiny sea fish in the small space of a decanter, "Aviary" speaks about a painful scene of the life of a mutated bird on the basis of human behaviors, and the poem" Cocks and Hens" describes the life of the hens in Aviculture. When encountered these poems, the reader understands the suffering of the hens in electronic cages to lay egg and deeply realize that the fish does not like to live in aquarium, the animal should use natural foods and be free in the nature. Also, he has masterfully described the consequences of destructing the nature in two lines of the poem "" Aviary":

"...On humans now

This mutant feeds..." (McGough, 1997, p. 90)

\subsection{Appreciation of rural life}

Regret and nostalgia for rural life and the appreciation of this kind of life has the most frequency in Iranian poets, "In iranian's children's poetry The village is an unreachable and dreamy place"(Nazar Ahari, 2000, p.10):

"I wish I could go back to the village/ go up to the hill in the village / above the hill I call you / from the missing village in halo of the moon" (Ebrahimi, 1992, p.18).

"What's there from which/ soot arises / soot from every side / falls on the earth /. . Yes, the town is there/ a town of smog" (Ebrahimi, 1993, p.24).

Also, the description of herds and shepherds and plains full of herds of cattle and sheep, harvest season, the appreciation of work of the sowers are the most repeated themes in these poems:

"when the night comes/ the sower is ready/to go to the farm and garden/ the spade on his shoulder/slowly goes out of the home/the country prosperous by the farmer /farmer was divine grace "(Yamini Sharifi, 1971, p. 35).

Such a theme can also be seen in the poems of English poets except that they obviously don't attack modern technology and urbanization phenomenon, but only describe this new lifestyle; apparently they encourage the readers to 
think and find a way to preserve the environment in the new modern life. For example, in the following poem, Michael Rosen describes lifestyle of seagulls in a coastal town:

"The seagulls think we live at the seaside: the tower blocks are their cliffs; they swoop for fish in the gutter but are happy that it's last night's fried rice.

They stand about screaming on the pavement beach

and ride the sea-breezes pumped out

by the cinema air-conditioning.

They hover over the waves of cars

and if you stare at them,

wondering what they're doing

so far from home,

they stare back:

'This is our home now.

That kebab

is a crab." (Rosen, 2010, unnumbered)

\subsection{Tthe Seasons}

Iranian poets have paid more attention to the spring, but these poems just describe a pleasant and beautiful spring without any imagination:

"Again blows the breath of spring / into streams and gardens and fields / again stream with songs /from greenery brings signs /again the fields / wears green dress of the spring /day and time again new / joyful message brings to you" (Dolat abadi, 1998, p.99).

"One flower, ten flowers, a hundred flowers / here, there, everywhere flowers / skirt, skirt in April / fall down on the world of flowers"(Kianoosh, 1991, p. 109).

And after spring, the poets have spoken about the autumn; two aspects of the autumn have drawn the attention of the poets, one is the deciduous and sorrow of the nature. Of course this sorrow is rare in the poems written in solar fifties in Iran, such as the works by Yamini Sharif and the Parvin Dolatabadi:

"In the autumn sunshine / warm, fine and pleasant /stand up we from the place / make ready everything / the harvest time

Blow autumn wind / yellow became all wheat /happy should be for this / that of any of our seeds /one hundred seeds the ground brings" (Yamini Sharifi, 1971, p. 36).

Another aspect is that the autumn is opening season for the schools, thus is accompanied by cheerfulness and joy:

"The schools are again opened/it's October, the month of hope and affection/comes the day to meet friends/can see again the face of the companions" (Dolat Abadi, 1998, p. 37).

After the autumn, it is the winter that has drawn the attention of Iranian poets and that because it is the season of snow fights and harbinger of the spring:

"Snow, herald of spring /winter falls /hi, hi whiteness /arrived last night" (ibid, 84).

"From the mountains of snow /blows wind of spring/tickles forcefully/ opened bud lips" (Kianoosh, 1991, p.16).

In poems where winter is the subject matter, the main theme revolves around speaking with the snow, sometimes it is asked to fall or sometimes thank it for falling.

Summer is rarely represented in the works of Iranian poets. However, where summer is the theme of the poem, the focus is mostly on summer fruits.

But a simple description of a season and a mere expression of natural beauties have not been the theme in the examined works of English poets They always avoid simple description and accompany the poem with an imagination or an exciting narrative that encounter the child with the characteristics of one of the season:

"who's killed the leaves?

Me, says the apple, l've killed them all

Who sees them drop?

Me, says the pear . they will leave me all bare.

Who'll cach their blood?

$\mathrm{Me}$, me, me, says the marrow, the marrow.

I'll get so rotund that they'll need a wheelbarrow.

Who will dig their graves?

Me, says the river, with the power of the clouds..." (Hughes. 1975, p. 43)

\section{Conclusion}


Iranian poets $2 \%$ more than English poets have focused on naturalistic themes. However, the main point in the final conclusion is that Iranian poets are still loyal to stereotypical characters and roles of animals in popular literature, of course in recent years, some poets have noticed the repetition of these stereotypes and for example have objected the stereotypes by the language of the animals or have changed their viewing angle to the animals. But, except one or two, other Iranian poets have never described the animal and its nature without intellectual background; animals still have still human personality in the Iranian children's poems.

In addition, Iranian poets often merely describe natural phenomena and element of fantasy and imagination is very rare in this group of poems; however, it should be said that mere description of the nature is not satisfactory for children, but also the situations that place the child in a specific relationship with those events and phenomena are interesting for him; in other word, looking at the phenomena from the eye of the child, getting a sense of him and its expression by a poetic language that is understandable.

Themes such as vegetarian, that is modern phenomena, are faded in Persian poetry and should be considered in the poetry.

A common point between the poets of both groups is the poems that focus on preservation of the environment. Both groups have paid significant attention to this subject matter.

\section{References}

Belali, R. (2000). "Goftogoo". Ketab e Mah e Koodak o Nojavan, 11.

Causley, C. (1973). Figgie Hobbin. New York: Walker.

Charpentreau, J. (1993)." The golden age of poetry". Seventeen Articles about children's literature. Tehran: shoraye ketab e koodak publications.

Dolat Abadi, P. (1998). Bar ghayegh e abrha [on clouds's boat]. Tehran: Rahgosha Publications.

Ebrahimi, J. (1992). Booye Gonjeshk [The smell of sparrows]. Tehran: Kanune Parvareshe Fekrie kudakan Va Nojavanan.

Nojavanan.

(1993). Ab mesle salam [Water like Hello]. Tehran: Tehran: Kanune Parvareshe fekrie kudakan Va

Ghasemnia, S. (1994). Mah o mahi [Moon and fish]. Tehran: Ghadyani publicatinons.

Hughes, T. (1975). Season songs. London: Penguin Publishing Group. (1978). Moon-Bells and other poems. London: Chatto and Windus.

. (1987). The Cat and the Cuckoo. Bideford: Sunstone Press.

. (2010). New and collected poems1957-1994. London: Faber \& Faber.

Keshavarz, N. (1998). Mivehayeshan salam sayehayeshan nasim[Hi is their fruit And their shadows is a breeze]. Tehran: Ghadyani publicatinons. . (2004). Az in taraf loftan faghat Hiss[Please, this way but slowly]. Mashhad: Behnashr Publications.

Kianoosh, M. (1990). Tooti e sabz e hendi [Green Hindi Parrot]. Tehran: Kanun e Parvaresh e Fekrie kudakan Va Nojavanan.

Nojavanan.

(1991). Bagh e setarehha [stars garden]. Tehran: Kanun e Parvaresh e Fekri e kudakan VA

Lockwood, M. (2009). "Ted Hughes: The development of a children's poet". Children's Literature in Education, Vol. 40, p. 296-305.

McGough, R. (1997). Bad Bad Cats. London: Puffin Books.

Nazar Ahari, E. (2000). "Dar Sher e Kudak Gorgi Dar Kamin Nist"[There in no wolf in children's poetry]. Pajuheshnameh Adabiat Kudak Va Nojavan, 21. PP.3-24.

Rosen, M. (2010). Michael's Big book of bad things. London: Ladybird.

Shabani, A. (1993). Akharin parande azad [The last free bird]. Tehran: Kanune parvareshe fekrie kudakan VA nojavanan.

Yamini sharif, A. (1971). Golhaye gooya [Talking flowers]. Tehran: Bongah e Tarjome Va Nashr e ketab Publications. . (2008). Avaz e soosk [Beetle's Song]. Tehran: Ravesh e No Publications.

Zephaniah, B. (1996). Funky Chickens. London: Viking/Penguin. 